\title{
NGHIÊN CƯ'U SỬ BIẾN ĐỔI NỒNG ĐỘ TROPONIN-T HUYẾT THANH Ở BỆNH NHÂN SAU PHẪU THUẬT VAN TIM
}

\section{Võ Đại Quyền", Đoàn Đúcc Hoằng*, Đặng Thế uyên* Huỳnh Văn Minh", Bùi Đức Phú *}

\section{TÓM TẮT}

Trong phẫu thuật tim, nồng độ Troponin-T huyết thanh gia tăng ở tất cả các bệnh nhân sau mổ, đỉnh cao nhất ở thời điểm 4 giờ sau mở cặp động mạch chủ là $1,184 \pm 0,675 \mathrm{ng} / \mathrm{ml}$. Sau đó, biến thiên nồng độ Troponin-T giảm dần và giá trị này ở thời điểm 24 giờ sau mở cặp động mạch chủlà $1,051 \pm 0,898 \mathrm{ng} / \mathrm{ml}$. Không có mối liên quan giữa nồng độ Troponin-T huyết thanh sau phẫu thuật vớicác yếu tổ về tuổi, giới, tăng áp lực động mạch phổitrước phẫu thuật. Có mối liên quan giữa nồng độ TnT sau mổ với các yếu tốđánh giá chức năng tim (NYHA, EF, LVtdD), và với các yếu tố nguy cơ (thời gian cặp động mạch chủ, thời gian tuần hoàn ngoài cơ thể, số van tim được can thiệp, thời gian thở máy, thời gian nằm hồi sức, suy thận cấp và trạng cung lượng tim thấp).

Kết luận: Nồng độ Troponin-T sau phẫu thuật là một chỉ điểm mức độ tổn thương cơ tim trong quá trình phẫu thuật có giá trị tiên lượng sớm ở các bệnh nhânsau phẫu thuật van tim.

Tù khóa: Troponin T, phẫu thuật van tim, yếu tố tiên lượng trong phẫu thuật tim.

\section{STUDY IN VARIATIONS OF SERUM TROPONIN-TLEVELS INPATIENTS AFTERHEART VALVE SURGERY}

\section{ABSTRACT}

Background: The concentration of serum troponin-T levels increased in all patients after surgery. The highest concentrationat the time of 4 hours after aortic clamp removingwith average value of $1.184 \pm 0.675 \mathrm{ng} / \mathrm{ml}$. The variation of troponin $\mathrm{T}$ levels decreasedgradually andthis value at the time of 24 hours afteraortic clamp removing was
$1.051 \pm 0.898 \mathrm{ng} / \mathrm{ml}$.There was no correlation between serum troponin $\mathrm{T}$ levels and factors of with age, sex, PAP. We found the correlationbetween TnTlevels and factors of cardiac functions (EF, NYHA, LVtdD), complex features of interventions (number of valves intervented, aortic clamping time, cardiopulmonarybypass time), results of intensive care (incidences of acute renal failure, of renal replacement therapy, of low cardiac output, of inotrope using; andartificialventilation time andICU time).

Conclusion: Troponin-T levelin postoperative period isamarkerofmyocardialdamageof patients undergoingheart valvesurgery. Itshould be considered asanearlyprognostic factorafterheartvalvesurgery.

Key words: Troponin $\mathrm{T}$, heart valve surgery, prognostic factor in cardiac surgery

\section{I- ĐẶT VẤN ĐỀ}

Bệnh lý van tim chiếm tỷ lệ khá cao trong các bệnh lý tim. Nguyên nhân chủ yếu là do thấp tim (hơn $90 \%$ tại các nước đang phát triển). Trong điều kiện Việt Nam hiện nay, đa số bệnh nhân van tim được phẫu thuật tương đối muộn, do đó tỷ lệ các tai biến cũng như tử vong sau phẫu thuật còn nhiều. Ngoài sự theo dõi chặt chẽ các diễn biến trên lâm sàng thì các yếu tố tiên lượngcó vai trò lớn góp phần phát hiện và điều trị sớm các biến chứng sau mổ nhằm đạt được kết quả tốt trong quá trình điều trị bệnh nhân sau phẫu thuật. Một trong những yếu tố đó là Troponin-T (TnT), được xem như một chỉ điểm sinh học chuyên

* Trung tâm Tim mạch, Bệnh viện Trung uoong Huế Người chịu trách nhiệm khoa học: GS.TS Bùi Đúc Phú

Ngày nhận bài: 27/05/2013 Email: buiducphu@gmail.com

Ngày Cho Phép Đăng: 13/06/2013

Phản Biện Khoa học: PGS.TS. Đặng Ngoc Hùng, PGS.TS. Lê Ngoc Thành 
biệt cho chẩn đoán tổn thương tế bào cơ tim hữu ích trong chẩn đoán nhồi máu cơ tim, nhất là các trường hợp nghi ngờ tăng creatine kinase giả hoặc nhồi máu nhỏ mà mức tăng creatine kinase không đủ ngưỡng để chẩn đoán.

Có nhiều nguyên nhân gây tổn thương tế bào cơ timdo tác động của phẫu thuật tim như bảo vệ cơ tim không đầy đủ, tổn thương tái tưới máu, tính chất phức tạp của các cuộc phẫu thuật.Sự tổn thương cơ tim này làm tăng Troponin $\mathrm{T}$ ở giai đoạn sau mổ dẫn đến sự xuất hiện của những biến cố sau phẫu thuật tim. Sự tăng của Troponin $\mathrm{T}$ được quan sát sau hầu hết các phẫu thuật tim hở, đã có nhiều nghiên cứu về giá trị tiên lượng của Troponin $\mathrm{T}$ sau phẫu thuật tim hở nói chung đặc biệt trong phẫu thuật cầu nối động mạch vành. Tuy nhiên chưa có nghiên cứu về vai trò tiên lượng của Troponin-T ở bệnh nhân được phẫu thuậtđiều trị bệnh lý van tim. Vì vậy chúng tôi thực hiện đề tài: "Nghiên cưu nồng độ Troponin T huyết thanh ở bệnh nhân sau phẫu thuật van tim" nhằm 2 mục tiêu:

1. Khảo sát sự biến đổi nồng độ Troponin-T huyết thanh ở bệnh nhân sau phẫu thuật van tim;

2. Tìm hiểu mối liên quan giữa giá trị này với các yếu tố tiên lượng sớm trong phẫu thuật van tim.

\section{II- ĐỐI TƯợNG VÀ PHƯƠNG PHÁP NGHIÊN CÚU}

Nghiên cứu ngẫu nhiên các bệnh nhân được phẫu thuật van tim tại Trung tâm tim mạch - Bệnh viện Trung ương Huế từ tháng 5-2011 đến tháng 5-2012.
Tiêu chuẩn chọn bệnh: gồm các bệnh nhân có chẩn đoán bệnh lý van 2 lá và/hoặc van động mạch chủ và/hoặc van 3 lá; cũng như các bệnh nhân này có chỉ định phẫu thuật sữa chữa hoặc thay van tim nhân tao theo khuyến cáo của ACC/AHA [1].

Tiêu chuẩn loại trừ: Bệnh nhân có bệnh lý mạch vành phối hợp;có bệnh lý hô hấp cấp hoặc mạn trước phẫu thuật, có rối loạn chức năng thận trước phẫu thuật, có nồng độ TnT cao hơn giá trị bình thường ngay trước phẫu thuật ( $\operatorname{TnT}>0,1 \mathrm{ng} / \mathrm{ml})$, và các bệnh nhân còn rối loạn chức năng các van tim sau mổ đáng kể như còn hở van hai lá $>2 / 4$, hoặc còn chênh áp cao sau thay van động mạch chủ,các trường hợp đặc biệt chảy máu nặng sau phẫu thuật cần thiết phải mở ngực cầm máu và nhiễm trùng sau mổ.

Các bệnh nhân này được định lượng nồng độ Troponin-T ở các thời điểm: ngay trước khi bắt đầu phẫu thuật, 4giờ và 24 giờ sau mở cặp động mạch chủ và được chia làm 3 nhóm tùy theo nồng độ $\mathrm{TnT}$ thời điểm 4 giờ sau mở cặp ĐMC: nhóm $<0,8 \mathrm{ng} / \mathrm{ml}$, nhóm $0,8-1,3 \mathrm{ng} / \mathrm{ml}$ và nhóm $>1,3 \mathrm{ng} / \mathrm{ml}$. Trong mỗi nhóm tiến hành nghiên cứu mối tương quan giữa nồng độ TnT với các yếu tố tiên lượng khác như tuổi, giới, tăng áp phổi, các thông số đánh giá chức năng tim (NYHA, EF, LVtdD), các yếu tố đánh giá tác động của phẫu thuật (thời gian cặp động mạch chủ, thời gian tuần hoàn ngoài cơ thể, số van tim đượccan thiệp). Ngoài ra nghiên cứu tương quan giữa nồng độ TnT với các kết quả hồi sức sau mổ (biến chứng suy thận cấp và liệu pháp thay thế thận; tình trạng cung lượng tim thấpvà liệu pháp inotrope; kết quả về thời gian thở máy, thời gian điều trị tại phòng hồi sức tim).

\section{III- KẾT QUẢ NGHIÊN CỨU}

- Tất cả bệnh nhân đều có nồng độ TnT trong giới hạn bình thường trước lúc mổ.

Bảng 1: Nồng độ TnT tại các thời điểm sau mổ

\begin{tabular}{|c|c|c|c|}
\hline TnT & Max & Min & Trung bình \\
\hline 4h sau mở cặp ĐMC & 4,68 & 0,35 & $1,184 \pm 0,675$ \\
\hline 24h sau mở cặp ĐMC & 7,24 & 0,29 & $1,051 \pm 0,898$ \\
\hline
\end{tabular}


Bảng 2: Liên quan giũua TnT và các yếu tố nguy cơ trước mổ

\begin{tabular}{|c|c|c|c|c|c|}
\hline \multicolumn{2}{|c|}{ Yếu tố nguy cơ } & $\mathrm{TnT}<0,8 \mathrm{ng} / \mathrm{ml}$ & $\mathrm{TnT} 0.8-1.3 \mathrm{ng} / \mathrm{ml}$ & $\mathrm{TnT}>1.3 \mathrm{ng} / \mathrm{ml}$ & $\mathrm{P}$ \\
\hline \multicolumn{2}{|c|}{ Tuổi $>40$} & $26(38.8 \%)$ & $18(26.9 \%)$ & $23(34.3 \%)$ & $>0.05$ \\
\hline \multicolumn{2}{|l|}{ Nam } & $14(36 \%)$ & $12(31 \%)$ & $13(33 \%)$ & $>0.05$ \\
\hline \multicolumn{2}{|c|}{ NYHA III- IV } & $1(3.1 \%)$ & $13(40.6 \%)$ & $14(20 \%)$ & $<0.01$ \\
\hline \multicolumn{2}{|c|}{$\mathrm{FE}<50 \%$} & $12(28 \%)$ & $11(25.6 \%)$ & $20(46.4 \%)$ & $<0.05$ \\
\hline \multicolumn{2}{|c|}{ ĐKTTr TT $>55$} & $8(25.8 \%)$ & $5(16.1 \%)$ & $18(58.1 \%)$ & $<0.01$ \\
\hline \multicolumn{2}{|c|}{ PAPs $>60 \mathrm{mmHg}$} & $9(24.3 \%)$ & $14(42.4 \%)$ & $8(25 \%)$ & $>0.05$ \\
\hline \multirow{3}{*}{$\begin{array}{l}\text { Số van } \\
\text { tim can } \\
\text { thiệp }\end{array}$} & 1 & $19(63.3 \%)$ & $4(13.3 \%)$ & $7(23.4 \%)$ & \multirow[t]{3}{*}{$<0.01$} \\
\hline & 2 & $14(29.8 \%)$ & $19(40.4 \%)$ & $14(29.8 \%)$ & \\
\hline & 3 & $4(16 \%)$ & $10(40 \%)$ & $11(44 \%)$ & \\
\hline
\end{tabular}
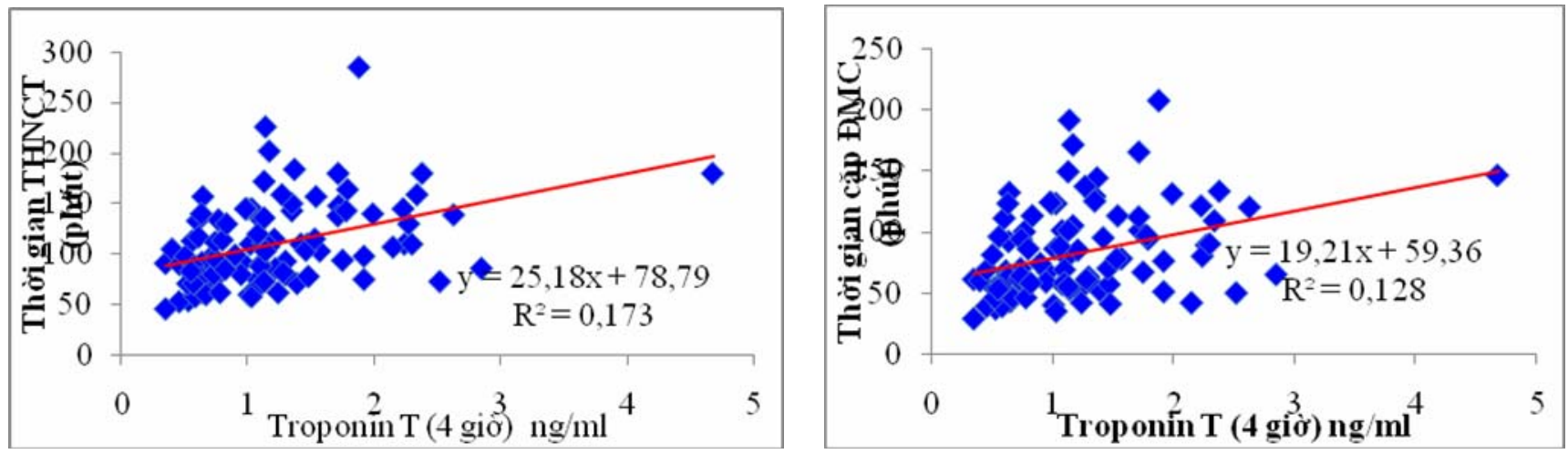

Biểu đồ 1: Tương quan giũa TnT và thời gian tuần hoàn ngoài co thể, thời gian cặp động mạch chủ

Bảng 3. TnT và các yếu tố nguy cơ sau mổ

\begin{tabular}{|l|c|c|c|c|c|}
\hline \multicolumn{2}{|l|}{ Yếu tố nguy cơ } & TnT $<0,8$ ng/ml & TnT 0.8- $1.3 \mathrm{ng} / \mathrm{ml}$ & TnT $>1.3 \mathrm{ng} / \mathrm{ml}$ & $\mathrm{P}$ \\
\hline FE sau mỗ $<50 \%$ & $11(28.9 \%)$ & $9(23.7 \%)$ & $18(47 \%)$ & $<0.05$ \\
\hline \multirow{2}{*}{ LCOS } & $1(4.2 \%)$ & $7(29.2 \%)$ & $16(66.7 \%)$ & $<0.01$ \\
\hline CN thận & $140-220$ & $1(2.7 \%)$ & $6(18.2 \%)$ & $10(31.3 \%)$ & $<0.01$ \\
\cline { 2 - 5 } & $>220$ & 0 & 0 & $10(31.3 \%)$ & $<0.01$ \\
\hline TG thở máy TB & $6,81 \pm 3,17$ & $12,70 \pm 8,05$ & $23,81 \pm 23,33$ & $<0.01$ \\
\hline TG điều trị HS TB & $3,09 \pm 0,9$ & $4,52 \pm 1,23$ & $5,81 \pm 1,87$ & $<$ \\
\hline
\end{tabular}




\section{IV- BÀN LUẬN}

Trong nghiên cứu của chúng tôi, tất cả bệnh nhân đều có nồng độ $\mathrm{TnT}$ huyết thanh ở giới hạn bình thường trước phẫu thuật. Nồng độ TnT trung bình ở thời điểm 4 giờ sau mở cặp ĐMC là $1,184 \pm$ $0,675 \mathrm{ng} / \mathrm{ml}$ và ở thời điểm 24 giờ sau mở cặp động mạch chủ là $1,051 \pm 0,898 \mathrm{ng} / \mathrm{ml}$. Như vậy, có sự tăng cao nhanh chóng của nồng độ TnT sau phẫu thuật tim, cao nhất ở thời điểm 4 giờ sau mở cặp ĐMC. Ở thời điểm 24 giờ sau mở cặp ĐMC nồng độ TnT có giảm nhẹ như trong nghiên cứu của James L. Januzzi. Kết quả này phù hợp với diễn biến của nồng độ $\mathrm{TnT}$ sau phẫu thuật tim hở với nồng độ TnT tăng khoảng hơn 10 lần giá trị giới hạn cao của TnT. Sự tổn thương cơ tim trong phẫu thuật tim ở bệnh nhân không có bệnh lý mạch vành kèm theo là tổn thương lan toả, sự tưới máu vành sau đó là bình thường cộng với sự tăng tính thấm màng tế bào do phản ứng viêm hệ thống nên nồng độ TnT tăng cao rất sớm ngay sau khi mở cặp ĐMC. Tuy nhiên, quá trình giảm nồng độ $\mathrm{TnT}$ sau đó chậm và kéo dài do sự rối loạn chức năng của các cơ quan thải trừ.

Chúng tôi nhận thấy sự phân bố bệnh nhân theo nồng độ TnT ở các thời điểm đồng đều giữa các nhóm tuổi. Tương tự với nghiên cứu của Stephanie Lehrke [2] và nghiên cứu của Nahum Nesher [4], có liên quan giữa tuổi và nồng độ TnTnhưng không có ý nghĩa thống kê. Điều này chứng tỏ rằng sự tổn thương cơ tim trong lúc phẫu thuật phụ thuộc chủ yếu vào tình trạng bệnh lý của bệnh nhân và quá trình phẫu thuật, yếu tố tuổi không ảnh hưởng đến sự tổn thương cơ tim trong quá trình phẫu thuật. Chúng tôi nhận thấy không có mối liên quan giữa tuổi và nồng độ TnT.Sự phân bố bệnh nhân ở các nhóm theo giới cũng không có sự khác biệt có ý nghĩa. Khác với nghiên cứu của Nahum Nesher [4], có sự khác biệt có ý nghĩa với tỷ lệ nữ giới cao hơn ở nhóm có nồng độ TnT cao hơn. Điều này có thể do trong mẫu nghiên cứu của chúng tôi, tuổi trung bình thấp hơn nên ít chịu sự ảnh hưởng của những thay đổi về nội tiết và mô hình bệnh lý tim mạch cũng khác hơn.

Ở thời điểm 4 giờ sau mở cặp ĐMC, có sự khác biệt về tỷ lệ phân bố theo NYHA giữa 3 nhóm theo nồng độ TnT. Tình trạng suy tim càng nặng thì khả năng tổn thương cơ tim trong quá trình phẫu thuật càng cao. Sự khác biệt này có ý nghĩa với $\mathrm{p}<0,01$.

Ngoài ra chúng tôi nhận thấy có sự khác biệt về phân bố bệnh nhân có giảm EF giữa các nhóm theo nồng độ $\operatorname{TnT}(\mathrm{p}<0,05)$. Nhóm có phân suất tống máu giảm phân bố chủ yếu ở nhóm có nồng độ TnT cao và ngược lại, nhóm có $\mathrm{EF}$ bình thường phân bố chủ yếu ở nhóm có nồng độ TnT thấp. Sự giảm nặng EF chứng tỏ ảnh hưởng của bệnh lý van tim lên cấu trúc và chức năng tim rất lớn dẫn đến khả năng chịu đựng thiếu máu kém và dễ bị tổn thương.TnT đã được sử dụng để ước lượng kích thước ổ nhồi máu trong các trong hợp nhồi máu cơ tim. Trong các bệnh lý van tim, các tâm thất thường dãn lớn theo thời gian, sự dãn lớn này làm cho việc bảo vệ cơ tim trong quá trình phẫu thuật khó khăn và cơ tim dễ bị tổn thương hơn. Mặc dù không thể xác định chính xác khối lượng cơ tim tổn thương, nhưng chúng tôi nghĩ rằng sự dãn chủ yếu buồng thất trái thông qua kết quả đo lường đường kính tâm trương thất trái trước phẫu thuật. Có sự khác biệt về phân bố của sự dãn buồng thất trái theo các nhóm dựa vào nồng độ TnT và tỷ lệ bệnh nhân có đường kính tâm thu thất trái dãn lớn phân bố ưu thế ở nhóm có nồng độ TnT cao, sự khác biệt này có ý nghĩa thống kê $(\mathrm{p}<0,05)$. Có $58,1 \%$ bệnh nhân bị dãn thất trái phân bố ở nhóm có nồng độ $\mathrm{TnT}>1,3 \mathrm{ng} / \mathrm{ml}$.Điều này được lý giải bởi sự tổn thương cơ tim trong phẫu thuật van tim là sự tổn thương có hồi phục của toàn bộ khối cơ tim nên khối cơ tim càng lớn thì sự phóng thích TnT càng nhiều. Có mối liên quan giữa đường kính tâm trương thất trái trước phẫu thuật và nồng độ $\mathrm{TnT}$ các thời điểm sau phẫu thuật.

Áp lực động mạch phổi tăng $>60 \mathrm{mmHg}$ là một trong những yếu tố tiên lượng của EUROscore và Parsonnet score. Trong nghiên cứu của chúng tôi, sự khác biệt về mức độ tăng áp lực động mạch phổi giữa các nhóm theo TnT không có ý nghĩa thống kê. Điều này có thể do trong nghiên cứu của chúng tôi, mẫu nghiên cứu chỉ gồm các bệnh lý về van tim trong đó bệnh hẹp van 2 lá thường gây tăng áp động mạch phổi 
rất nặng dù chức năng tim bình thường hoặc giảm nhẹ và kích thước thất trái chưa dãn nhiều.

Nồng độ TnT là thấp ở nhóm bệnh nhân được can thiệp một van tim, ngược lại tỷ lệ các bệnh nhân được phẫu thuật can thiệp ba van chiếm tỷ lệ cao ở nhóm có nồng độ TnT cao, sự khác biệt này có ý nghĩa thống kê với $\mathrm{p}<0,05$. Điều đó chứng tỏ có mối liên quan giữa số lượng van tim can thiệp và nồng độ TnT sau phẫu thuật hay nói cách khác, có mối liên hệ giữa nồng độ TnT sau phẫu thuật với mức độ phức tạp của phẫu thuật van tim.

Chúng tôi nhận thấy có mối tương quan thuận khá chặt chẽ giữa thời gian THNCT và nồng độ TnT huyết thanh ở thời điểm 4 giờ sau mở cặp ĐMC có hệ số tương quan $\mathrm{r}=0,417(\mathrm{p}<0,01)$. Điều này có nghĩa là thời gian tuần hoàn ngoài cơ thể càng dài thì nguy cơ tổn thương cơ tim càng lớn. Kết quả này tương tự với kết quả nghiên cứu của Nahum Nesher và cộng sự, trong nghiên cứu này thời gian THNCT trung bình của 2 nhóm có nồng độ $\mathrm{TnT}<0,8 \mathrm{ng} / \mathrm{ml}$ và $>0,8 \mathrm{ng} / \mathrm{ml}$ lần lượt là 100 phút và 119 phút với $\mathrm{p}<0,0001$ [5]. Nghiên cứu của Stephanie Lehrke và cộng sự cũng cho thấy sự khác biệt có ý nghĩa về thời gian THNCT giữa 2 nhóm theo nồng độ TnT [2]. Thời gian cặp ĐMC là thời gian mà cơ tim bị thiếu máu nuôi hoàn toàn, mặc dù sự tưới máu từng đợt mỗi 20 phút giúp loại bỏ các sản phẩm chuyển hoá của mô cơ tim và giúp tế bào cơ tim tránh bị tổn thương vĩnh viễn, thời gian này kéo dài làm tích luỹ các tổn thương thiếu máu của cơ tim. Vì vậy, thời gian cặp ĐMC càng dài thì nguy cơ và mức độ mức độ tổn thương cơ tim càng nặng. Trong nghiên cứu của Nahum Nesher [4] ghi nhận sự khác biệt về thời gian cặp ĐMC giữa các nhóm theo TnT rất có ý nghĩa với $\mathrm{p}<0,0001$.Trong nghiên cứu của chúng tôi, ở thời điểm 4 giờ sau mở cặp ĐMC, có sự tương quan thuận khá chặt chẽ giữa nồng độ $\mathrm{TnT}$ và thời gian cặp ĐMC với hệ số tương quan $\mathrm{r}$ $=0,359(\mathrm{p}<0,01)$.

Các bệnh nhân giảm phân suất tống máu sau phẫu thuật chiếm tỷ lệ cao ở nhóm có nồng độ TnT cao, 47,4\% ở nhóm > 1,3ng/ml. Các trường hợp có chức năng thất trái bảo tồn sau phẫu thuật phân bố chủ yếu ở nhóm nồng độ TnT thấp $(\mathrm{p}<0,05)$. Nồng độ TnT sau phẫu thuật van tim là một yếu tố tiên lượng cho khả năng hồi phục chức năng thất trái sau phẫu thuật van tim.

Theo nghiên cứu của chúng tôi, tỷ lệ xuất hiện tình trạng cung lượng tim thấp (LCOS)tăng dần theo các nhóm ở thời điểm 4 giờ sau mở cặp $\mathrm{ĐMC}$, từ $4,2 \%$ ở nhóm 1 , tăng lên $29,2 \%$ ở nhóm 2 và tăng đột biến lên $66,7 \%$ ở nhóm $3(\mathrm{p}<0,01)$. Chúng tôi nhận thấy rằng với nồng độ $\mathrm{TnT}$ sau mở cặp $\mathrm{DMC}$ có giá trị dự báo cho khả năng xuất hiện LCOS trong quá trình điều trị tại phòng hồi sức sau phẫu thuật. Như vậy, với nồng độ $\mathrm{TnT}$ càng cao chứng tỏ sự tổn thương cơ tim càng lớn gây nên khả năng rối loạn chức năng tim sau phẫu thuật càng cao, biểu hiện bởi LCOS sau phẫu thuật.Kết quả của chúng tôi tương tự như kết quả nghiên cứu của Nahum Nesher với sự khác biệt về tỷ lệ xuất hiện LCOS giữa các nhóm có ý nghĩa với $\mathrm{p}<0,0001$.

Trong kết quả nghiên cứu, có 10 trường hợp có suy thận cấp và đều nằm trong nhóm có nồng độ $\mathrm{TnT}>1,3 \mathrm{ng} / \mathrm{ml}$ ở thời điểm 4 giờ sau mở cặp ĐMC. Chức năng thận bình thường chiếm ưu thế ở các nhóm có nồng độ TnT thấp, tỷ lệ rối loạn chức năng thận cũng tăng dần giữa các nhóm, từ $2,7 \%$ ở nhóm 1 , tăng lên $18,2 \%$ ở nhóm 2 và $31,3 \%$ ở nhóm 3 . Sự khác biệt rất có ý nghĩa với $\mathrm{p}<0,01$. Sự gia tăng nồng độ TnT sau phẫu thuật là một yếu tố dự báo cho khả năng xảy ra suy thận cấp trước thận do suy chức năng tuần hoàn ở bệnh nhân phẫu thuật van tim. Các bệnh nhân này được điều trị thay thế thận bằng cách sử dụng phương pháp thẩm phân phúc mạc, đây là phương pháp điều trị đã được sử dụng có hiệu quả tại nhiều trung tâm tim mạch tại Việt Nam và thế giới. Có 3 trường hợp cần thẩm phân phúc mạc và đều nằm trong nhóm có nồng độ $\mathrm{TnT}>1,3 \mathrm{ng} / \mathrm{ml}$.Kết quả của chúng tôi tương tự với kết quả nghiên cứu của Nahum Nesher [4].

Kết quả điều trị tại hồi sức như thời gian thở máy trung bình của 3 nhóm ở thời điểm 4 giờ sau mở cặp ĐMC có sự khác biệt rất rõ ràng với 6,8 giờ ở nhóm $1 ; 12,7$ giờ ở nhóm 2 và 23,8 giờ ở nhóm $3(\mathrm{p}<0,01)$. Nhóm có nồng độ $\mathrm{TnT}$ càng cao thì thời gian thở máy càng dài chứng tỏ sự tổn thương cơ tim nặng sẽ dẫn đến tình trạng khó để đạt được những tiêu chí 
cho việc cai máy thở. Kết quả của chúng tôi phù hợp với kết quả nghiên cứu của Nahum Nesher và cộng sự với sự khác biệt về thời gian thở máy giữa các nhóm nghiên cứu $(p<0.0001)$ [3]. Do đó, chúng tôi có thể kết luận nồng độ TnT sau phẫu thuật van tim là một yếu tố dự báo cho khả năng thở máy kéo dài sau phẫu thuật.Tương tự, kết quả về thời gian nằm hồi sức cũng có sự khác biệt giữa các nhóm nghiên cứu, thời gian điều trị hồi sức trung bình là 3,1 ngày, nhóm 2 là 4,5 ngày và nhóm 3 là 5,8 ngày $(\mathrm{p}<0,01)$. Như vậy, mức độ tổn thương cơ tim càng nặng trong quá trình phẫu thuật sẽ dẫn đến sự hồi phục chậm hơn của các hệ cơ quan làm kéo dài thời gian điều trị ở phòng hồi sức gây tốn kém chi phí và đối diện với nhiều nguy cơ của việc điều trị. Nghiên cứu của Nahum Nesher cũng cho thấy sự khác biệt về thời gian điều trị hồi sức trung bình giữa các nhóm dựa theo nồng độ TnT $(\mathrm{p}<$ $0,0001)$. Mối liên quan giữa thời gian điều trị hồi sức và nồng độ $\mathrm{TnT}$ cũng được xác lập trong nghiên cứu của Stephanie Lehrke và cộng sự với $\mathrm{p}<0,001$.

\section{V- KẾT LUẬN}

Qua nhiên cứu 102 bệnh nhân sau phẫu thuật van tim tại BVTW Huế, chúng tôi có một số kết luận bước đầu như sau : Nồng độ TnT tăng sau tất cả các trường hợp phẫu thuật van tim. Cao nhất ở thời điểm 4 giờ sau mở cặp ĐMC sau đó giảm dần. Nồng độ Troponin-T huyết thanh ở thời điểm 4 giờ sau mở cặp động mạch chủlà $1,184 \pm 0,675 \mathrm{ng} / \mathrm{ml}$, và giá trị này ở thời điểm 24 giờ sau mở cặp động mạch chủ là $1,051 \pm 0,898 \mathrm{ng} / \mathrm{ml})$. Nồng độ TnT là một yếu tố quan trọng để đánh giá tình trạng tổn thương cơ tim trong quá trình phẫu thuật. Giá trị này có ý nghĩa tiên lượng góp phần đạt được kết quả điều trị cho bệnh nhân phẫu thuật van tim. Nồng độ TnT còn có tương quan với các yếu tố tiên lượng trước, trong và sau phẫu thuật tim.Giá trị này tương quan thuận khá chặt chẽ giữa nồng độ $\mathrm{TnT}$ và thời gian cặp ĐMC với hệ số tương quan $r=0,359(\mathrm{p}<0,01)$; tương quan thuận khá chặt chẽ giữa thời gian $\mathrm{THNCT}$ và nồng độ $\mathrm{TnT}$ huyết thanh ở thời điểm 4 giờ sau mở cặp ĐMC có hệ số tương quan $\mathrm{r}=0,417(\mathrm{p}<0,01)$. Troponin- $\mathrm{T}$ được xem như là một chỉ điểm cho tổn thương cơ tim trong quá trình phẫu thuật và là một yếu tố tiên lượng ngay sau phẫu thuật.

\section{TÀI LIỆU THAM KHẢO}

1. Bonow R. O. , Carabello B., Edmunds L. Henry (2006), "Guidelines for the management of patients with valvular heart disease", $A C C / A H A$ practice guidelines, pp.1949 - 1984.

2. Lehrke Stephanie and al (2000), "Cardiac Troponin $\mathrm{T}$ for Prediction of Short- and LongTerm Morbidity and Mortality after Elective Open Heart Surgery", Clinical Chemistry 50, pp. 1560- 1567.

3. Lurati Buse Giovana A. and al (2009), "12Month Outcome after cardiac surgery: Prediction by Troponin $\mathrm{T}$ in Combination With the European system for Cardiac Operative Risk Evaluation", The Society of Thoracic Surgeons, pp.1806- 1811.

4. Nesher Nahum and al (2008), "TnT after Cardiac Surgery: A Predictor or a Phenomenon", The Society of Thoracic Surgeons, pp. 1348- 1354.

5. Vermes Emmanuelle and al (2000), "Cardiac Troponin I release after open Heart Surgery: A Marker of Myocardial Protection", The Society of Thoracic Surgeons, pp. 2087-2090. 